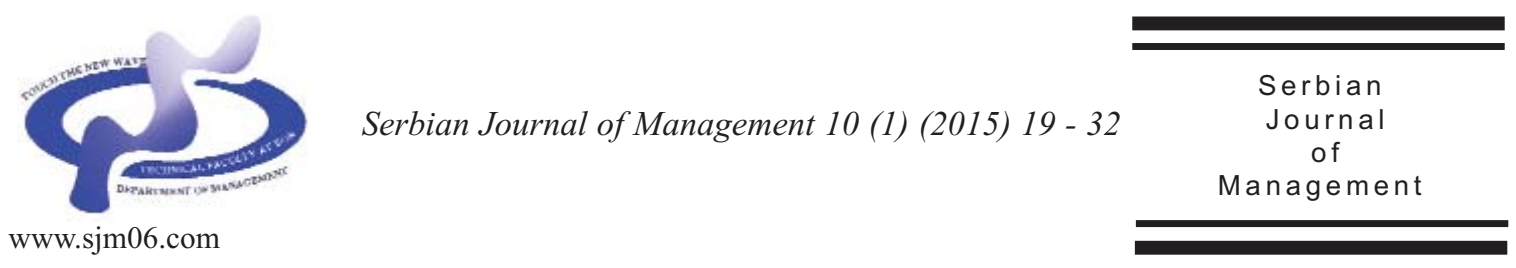

\title{
UNEARTHING GLOBAL FINANCIAL INCLUSION LEVELS AND ANALYSIS OF FINANCIAL INCLUSION AS A MEDIATING FACTOR IN GLOBAL HUMAN DEVELOPMENT
}

\author{
Roshny Unnikrishnan ${ }^{*}$ and Lakshmi Jagannathan ${ }^{b}$

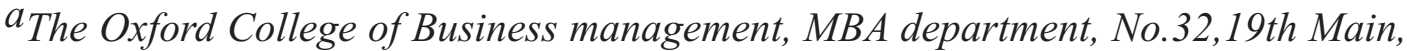 \\ 17th B Cross, Sector IV, HSR Layout, Bengaluru Karnataka, Postal code:560102, India

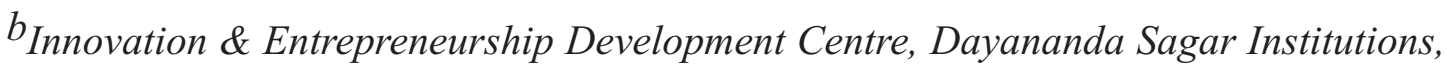 \\ Kumaraswamy Layout, Bengaluru, Karnataka, Postal code: 560 078, India
}

(Received 20 January 2014; accepted 30 September 2014)

\begin{abstract}
This study is a result of the author's inquisition to unearth the current values of Global Financial Inclusion and its relationship with economic growth measured by Gross Domestic product(GDP) and human development measured by United Nations Human Development Index (HDI). The Financial Inclusion (FI) levels are measured using Index for Financial Inclusion .The relationship between GDP and HDI with FI as mediator, using multiple regression, is validated on a global level based on data of 162 countries for the year 2011. An overall global mediation analysis is undertaken to establish Financial Inclusion as a mediating factor and partial mediation on human development is validated. The study is valid and unique in the global context of income inequality prevailing in developed, developing and underdeveloped countries as it validates the argument that an impressive GDP performance does not ensure equity in economic growth.
\end{abstract}

Keywords: gross domestic product (GDP), financial inclusion (FI), human development index (HDI), mediation analysis, multiple regression analysis

"Where a great proportion of people are suffered to languish in helpless misery, that country must be ill policed, and wretchedly governed; a decent provision for the poor is the true test of civilization." -Samuel Johnson, 1791

\footnotetext{
* Corresponding author: roshnyunnikrishnan@gmail.com DOI:10.5937/sjm10-5363
} 


\section{INTRODUCTION}

Development of overall finance in an economy contributes positively to economic growth, physical capital accumulation and overall efficiency of the economy. It is found that financial development is seen to contribute robustly in both the current and future rate of economic growth as suggested by Schumpeter, decades ago. There is ample evidence from the history of economies that financial development with respect to measures such as access to credit, liquidity, assets and liabilities of financial institutions are positively related to economic growth (King \& Levine, 1993; Levine \& Zervos,1998; Arranz Garcia \& Vicente Lorente, 2014). The need for Financial Inclusion (FI) is recognised globally as a precondition for economic growth and alleviating poverty. Financial Inclusion refers to accessibility, availability and usage of the formal financial system for all the people in an economy (Kumar \& Mohanty, 2011). Financial inclusion also implies to provide access to payments and remittance facilities, affordable financial services, savings, loans and insurance services by formal financial system (Nagadevara, 2009). In the absence of Inclusive financial systems, poor people are forced to rely on their own limited savings thus limiting their access to education and in pursuing promising opportunities as resilient entrepreneurs ultimately leading to income inequality and slower economic growth of a country. Analysis of Global Findex data reveals that account penetration as a part of financial inclusion tends to be higher in higher income countries having higher Gross Domestic Product (Demirguc-Kunt \& Klapper, 2012). The purpose of the current study is to unearth the current levels of Global Financial inclusion and analyse whether the improvement in Financial Inclusion levels contributes to higher Global Human development.

\section{GROSS DOMESTIC PRODUCT (GDP) AND HUMAN DEVELOPMENT INDEX (HDI) AS MEASURES OF DEVELOPMENT}

Measuring human development in absolute terms has always been a challenge for global regulatory organisations. The (Gross Domestic Product) GDP concept based on National income concepts has been a globally accepted measure of development of a country. "GDP measures final purchases by households, business, and government by summing consumption, investment, government spending, and net exports" (US Department of Commerce, 2000). The three ways to measure GDP is Value-added or production approach, Income approach and Final demand or Expenditure approach (Landefeld et al., 2008). GDP as a measure of economic growth has been debated from the 1970's (Henderson, 1996). The GDP fails to measure equitable distribution of income, socio political considerations as well as other social and economic benefits produced in the society. (Nissan \& Shahmoon, 1993). The GDP as a measure of economic growth is seen to have the following caveats undervaluing of services, undervaluing national assets like environment and infrastructure, ignoring "informal sectors" like volunteer work and women's contribution to society, measuring income as an average of all population irrespective of distribution pattern, thereby ignoring poverty, combining monetary and non monetary measures into single index. It was 
suggested that environmental and quality-oflife indicators and remedies for all the caveats should also be incorporated into GDP. GDP growth should be recognised as means to an end -human development and survival under drastically changing conditions (Henderson, 1996).

Integrating socio economic development with human resource development and eliminating poverty consists of two main issues with respect to choosing main variables and constructing an index to enable comparison between nations. (Nissan \& Shahmoon, 1993). Human wellbeing is considered as multidimensional and many indexes such as Physical Quality of Life index, United Nations Research Institute for Social Development's General Index of Development, Index of Economic Freedom, Gender-Related Development Index (GDI), Gender Empowerment Measure (GEM), Human Poverty Index (HPI) and Human Development Index (HDI) (Takuyama \& Pillarisetti, 2009). The most successful measure overcoming the caveats of GDP as a measure of economic growth has been HDI launched in 1990 by United Nations Human Development Report. HDI is a country centred ranking based on three dimensions forming a third of the whole, namely longevity, education and per capita income in terms of PPP (Ogwang, 2000; Luchters \& Menkoff, 2000; Henderson, 1996). Enrolment and literacy statistics are combined in a proportion of one-third and two-thirds to depict education in a country (Cahill, 2005). HDI is based on the minimum and maximum of each dimension, for a specific time period, commonly referred to as "goalposts". The basic assumption of HDI that people across the globe aspire, for a long and healthy life, maintenance of a decent standard of living and to acquire knowledge.
These assumptions form the pillars of HDI. All variables are normalised with appropriate adjustments (Takuyama \& Pillarisetti, 2009). The indicators derive a value between 0 and 1 and higher the value, higher the human development level (Ogwang, 2000). HDI emphasizes "the fact that economic development is not only about raising output or income but also enlarging human choices and enriching lives" (Low \& Aw, 1997).

It is seen that values of composite indexes such as HDI pertaining to low income developing nations are not reliable and dependable. The metrics of converting population in millions to smaller numbers have resulted in countries having less than half million population having zero population when the numbers are rounded off in decimals when formatting spreadsheets of data (Takuyama \& Pillarisetti, 2009). HDI Index of measuring human development is criticised for being a simple average of the three variables life expectancy, educational attainment and adjusted real GDP per capita. However the concept of normalisation, the basic principle behind HDI calculations include calculation of minimum and maximum values often described as "moving the goal posts". This makes comparison difficult between time periods as the standards are revised based on the scores in respective time periods (Low \& Aw, 1997). In spite of all the criticisms, the fact remains that the development of HDI was a breakthrough from traditional onedimensional indicators and a more comprehensive and meaningful measure of human development (Porter \& Purser, 2008).

\section{THE CURRENT STUDY}

Study conducted on growth in HDI over a period of 15 years from 1985 to 2000 for 82 
developing countries have revealed that the averages for the countries does not vary from the value of 0.55 in the year 1985 to a value of 0.59 in the year 2000 (Hajro \& Joyce, 2009). It is seen that in some cases the growth in HDI occurs at a higher rate than growth in GDP. Per capita GDP is seen to have diminishing returns to human development. Higher levels of HDI are associated with higher levels of GDP, but at a diminishing rate (Cahill, 2002). HDI recognises a component of overall well being as having "access to resources". HDI uses GDP to measure "command over resources" (Osberg \& Sharpe, 2005), but access to resources equitably can be measured by assessing the Financial Inclusion level in an economy. Human development ultimately needs to be measured in three perspectives, national average, equity and deprivation (Fukuda-Parr, 2001) whereas the current index HDI limits measurement to national average. In this study attempt is made to integrate Equity into the index as a mediating factor in terms of Financial Inclusion, resulting in higher human development than just emphasising on GDP growth.

The Current study consists of two parts To understand the financial inclusion status globally - calculating the financial inclusion levels using IFI index and Ranking countries based on Financial Inclusion levels, and to establish Financial inclusion as a variable which considerably boost the human development - validating the model showing the relationship between GDP and HDI with Financial Inclusion as the mediator variable as in Figure 1.

To achieve the objective of validating the framework, data was collected for 162 countries based on United nation Economies per capita in GNI (Gross National Income) in the year 2011, classified as in Table 1.
Table 1. Classification of Countries based on GNI

\begin{tabular}{lc}
\hline Classification of Countries & Number of Countries \\
\hline High Income countries & 49 \\
Upper Middle Income & 43 \\
Lower Middle income & 38 \\
Low-Income & 32 \\
Total & 162
\end{tabular}

The complete data for all dimensions of financial inclusion was available for 117 countries and are used in this study. All figures used are for the year 2011 and where the data was not available for the year, the latest available data has been used for all calculations.

\section{FINANCIAL INCLUSION - EMPIRICAL RESULTS}

The Financial Inclusion levels are calculated based on the Index for Financial Inclusion (IFI), based on three dimensions namely - Penetration (Percentage of population with Bank accounts), Availability (Number of Bank Branches per 100000), Usage (Credit as percentage of GDP \& Deposit as percentage of GDP). A dimension Index is calculated for each dimension, and the Financial Inclusion levels are unearthed using the formula as under.

$I F I=1-\frac{\sqrt{\left(1-d_{1}\right)^{2}+\left(1-d_{2}\right)^{2}+\left(1-d_{3}\right)^{2}+\left(1-d_{4}\right)^{2}}}{n}(1)$

Where:

$d_{1}=$ Dimension index of Percentage of population with Bank accounts,

$d_{2}=$ Dimension index of Number of Bank Branches per 100000 ,

$d_{3}=$ Dimension index of Credit as percentage of GDP, 
$d_{4}=$ Dimension index of Deposit as Normalising the above dimensions, the percentage of GDP, $n=$ No: of Variables. Financial inclusion level of a country can be represented by a point in three dimensional

Table 2. Global Financial Inclusion (FI) Levels and Ranking - Year 2011

\begin{tabular}{|c|c|c|c|c|c|c|c|c|c|c|c|}
\hline $\begin{array}{l}\text { Country } \\
\text { Name }\end{array}$ & FI & 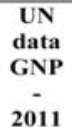 & $\begin{array}{c}\text { Global } \\
\text { Rank } \\
\text { based } \\
\text { on FI }\end{array}$ & $\begin{array}{l}\text { Country } \\
\text { Name }\end{array}$ & FI & $\begin{array}{c}\text { UN } \\
\text { data } \\
\text { GNP } \\
- \\
2011\end{array}$ & $\begin{array}{l}\text { Global } \\
\text { Rank } \\
\text { based } \\
\text { on FI }\end{array}$ & $\begin{array}{c}\text { Country } \\
\text { Name }\end{array}$ & FI & $\begin{array}{c}\text { UN } \\
\text { data } \\
\text { GNP } \\
- \\
2011\end{array}$ & $\begin{array}{c}\text { Global } \\
\text { Rank } \\
\text { based } \\
\text { on FI }\end{array}$ \\
\hline Cyprus & 0.8581 & $\mathrm{HI}^{\prime}$ & 1 & Morocco & 0.2948 & $\mathrm{LMI}^{3}$ & 40 & Angola & 0.1500 & LMI & 79 \\
\hline Luxembourg & 0.7537 & $\mathrm{HI}$ & 2 & Montenegro & 0.2885 & $\mathrm{HI}$ & 41 & Argentina & 0.1456 & MI & 80 \\
\hline Spain & 0.6839 & $\mathrm{HI}$ & 3 & Lithuania & 0.2841 & MI & 42 & Mozambique & 0.1414 & LI & 81 \\
\hline Japan & 0.6228 & HI & 4 & $\begin{array}{l}\text { Bosnia and } \\
\text { Herzegovina }\end{array}$ & 0.2815 & MI & 43 & Viet Nam & 0.1410 & LMI & 82 \\
\hline Portugal & 0.5829 & $\mathrm{HI}$ & 5 & Kuwait & 0.2800 & $\mathrm{HI}$ & 44 & Uruguay & 0.1408 & MI & 83 \\
\hline $\begin{array}{l}\text { Hong Kong } \\
\text { SAR }\end{array}$ & 0.5649 & HI & 6 & Hungary & 0.2719 & $\mathrm{HI}$ & 45 & Saudi Arabia & 0.1382 & $\mathrm{HI}$ & 84 \\
\hline Malta & 0.5118 & $\mathrm{HI}$ & 7 & $\begin{array}{l}\text { United Arab } \\
\text { Emirates }\end{array}$ & 0.2677 & $\mathrm{HI}$ & 46 & Nigeria & 0.1347 & LMI & 85 \\
\hline Italy & 0.4922 & $\mathrm{HI}$ & 8 & Qatar & 0.2652 & $\mathrm{HI}$ & 47 & Egypt & 0.1295 & LMI & 86 \\
\hline Ireland & 0.4696 & $\mathrm{HI}$ & 9 & Jordan & 0.2594 & MI & 48 & Botswana & 0.1259 & MI & 87 \\
\hline Netherlands & 0.4680 & $\mathrm{HI}$ & 10 & Turkey & 0.2567 & MI & 49 & $\begin{array}{l}\text { Republic of } \\
\text { Moldova }\end{array}$ & 0.1245 & LMI & 88 \\
\hline $\begin{array}{l}\text { United } \\
\text { States }\end{array}$ & 0.4630 & HI & 11 & $\begin{array}{l}\text { Russian } \\
\text { Federation }\end{array}$ & 0.2528 & MI & 50 & El Salvador & 0.1245 & LMI & 89 \\
\hline Belgium & 0.4523 & $\mathrm{HI}$ & 12 & Oman & 0.2468 & $\mathrm{HI}$ & 51 & Armenia & 0.1237 & LMI & 90 \\
\hline Canada & 0.4465 & $\mathrm{HI}$ & 13 & Panama & 0.2434 & MI & 52 & Indonesia & 0.1195 & LMI & 91 \\
\hline Denmark & 0.4406 & $\mathrm{HI}$ & 14 & Romania & 0.2422 & MI & 53 & Paraguay & 0.1176 & LMI & 92 \\
\hline Greece & 0.4395 & $\mathrm{HI}$ & 15 & Iran & 0.2416 & MI & 54 & Algeria & 0.1176 & MI & 93 \\
\hline France & 0.4372 & $\mathrm{HI}$ & 16 & Sri Lanka & 0.2357 & LMI & 55 & Ghana & 0.1165 & LMI & 94 \\
\hline Lebanon & 0.4319 & $\mathrm{Ml}^{2}$ & 17 & Serbia & 0.2252 & MI & 56 & Nicaragua & 0.1086 & LMI & 95 \\
\hline Australia & 0.4291 & HI & 18 & Costa Rica & 0.2212 & MI & 57 & Liberia & 0.1034 & LI & 96 \\
\hline $\begin{array}{l}\text { Republic of } \\
\text { Korea }\end{array}$ & 0.3850 & $\mathrm{HI}$ & 19 & Chile & 0.2205 & MI & 58 & Haiti & 0.0998 & LI & 97 \\
\hline Germany & 0.3821 & $\mathrm{HI}$ & 20 & Albania & 0.2201 & MI & 59 & Mauritania & 0.0946 & LMI & 98 \\
\hline Croatia & 0.3721 & $\mathrm{HI}$ & 21 & Tunisia & 0.2176 & MI & 60 & Pakistan & 0.0937 & LMI & 99 \\
\hline Slovenia & 0.3715 & $\mathrm{HI}$ & 22 & Jamaica & 0.2163 & MI & 61 & Malawi & 0.0879 & LI & 100 \\
\hline Austria & 0.3701 & $\mathrm{HI}$ & 23 & $\begin{array}{l}\text { Dominican } \\
\text { Republic }\end{array}$ & 0.2100 & MI & 62 & Comoros & 0.0876 & LI & 101 \\
\hline Sweden & 0.3632 & $\mathrm{HI}$ & 24 & India & 0.2085 & LMI & 63 & Zambia & 0.0865 & LMI & 102 \\
\hline Mauritius & 0.3612 & $\mathrm{HI}$ & 25 & Peru & 0.2001 & MI & 64 & Azerbaijan & 0.0811 & MI & 103 \\
\hline Thailand & 0.3609 & MI & 26 & Bangladesh & 0.1986 & $\mathrm{Ll}^{4}$ & 65 & $\begin{array}{l}\text { United } \\
\text { Republic of } \\
\text { Tanzania }\end{array}$ & 0.0811 & LI & 104 \\
\hline Brazil & 0.3589 & MI & 27 & Guatemala & 0.1928 & LMI & 66 & Togo & 0.0787 & $\mathrm{LI}$ & 105 \\
\hline Bulgaria & 0.3518 & MI & 28 & Venezuela & 0.1817 & MI & 67 & Uganda & 0.0787 & LI & 106 \\
\hline Malaysia & 0.3481 & MI & 29 & Kenya & 0.1769 & $\mathrm{LI}$ & 68 & Gabon & 0.0785 & MI & 107 \\
\hline Singapore & 0.3468 & HI & 30 & Honduras & 0.1740 & LMI & 69 & Lesotho & 0.0757 & $\mathrm{LI}$ & 108 \\
\hline Israel & 0.3465 & $\mathrm{HI}$ & 31 & Ukraine & 0.1731 & LMI & 70 & Cameroon & 0.0622 & LMI & 109 \\
\hline China & 0.3336 & MI & 32 & Nepal & 0.1669 & LI & 71 & Iraq & 0.0612 & LMI & 110 \\
\hline Latvia & 0.3185 & MI & 33 & Colombia & 0.1664 & MI & 72 & $\begin{array}{l}\text { Papua New } \\
\text { Guinea }\end{array}$ & 0.0474 & MI & 111 \\
\hline Finland & 0.3180 & $\mathrm{HI}$ & 34 & Georgia & 0.1653 & LMI & 73 & Guinea & 0.0473 & LI & 112 \\
\hline $\begin{array}{l}\text { Czech } \\
\text { Republic }\end{array}$ & 0.3102 & $\mathrm{HI}$ & 35 & Belarus & 0.1653 & MI & 74 & Yemen & 0.0407 & LMI & 113 \\
\hline Estonia & 0.3096 & $\mathrm{HI}$ & 36 & Philippines & 0.1598 & LMI & 75 & Madagascar & 0.0354 & LI & 114 \\
\hline Poland & 0.3078 & $\mathrm{HI}$ & 37 & Bolivia & 0.1561 & LMI & 76 & Chad & 0.0303 & LI & 115 \\
\hline South Africa & 0.3039 & MI & 38 & Mexico & 0.1512 & MI & 77 & Congo & 0.0267 & LMI & 116 \\
\hline Slovakia & 0.2971 & $\mathrm{HI}$ & 39 & Kazakhstan & 0.1510 & MI & 78 & $\begin{array}{l}\text { Equatorial } \\
\text { Guinea }\end{array}$ & 0.0224 & $\mathrm{HI}$ & 117 \\
\hline
\end{tabular}

Source: Computed based on data from - World Bank (2013), http://www.financebycountry.com (2013)

${ }^{1}$ HI- High Income,${ }^{2} \mathrm{MI}$-Middle Income , ${ }^{3}$ LMI - Lower Middle Income, ${ }^{4} \mathrm{LI}$ - Lower Income 
Cartesian space, such that $0 \leq d_{1}, d_{2}, d_{3}, d_{4} \leq 1$. The formula will derive values in the range of 0 to 1 where the value of 1 denotes perfect Financial Inclusion and value of 0 denotes perfect imbalance in Financial Inclusion (Sarma, 2008).

The IFI has been calculated for 117 countries based on the available data with respect to all four dimensions as specified in the IFI formula as proposed by Mandira Sarma (2008). Lebonon being a Middle income country, enjoys $17^{\text {th }}$ rank globally showing highly equitable distribution of wealth, whereas Equatorial Guinea, categorised as High Income country, enjoys the $117^{\text {th }}$ rank, or extreme inequality in wealth distribution. Other High Income countries like Saudi Arabia (84th Rank), Oman (51 th Rank), Qatar (47 th Rank), United Arab Emirates (46 th Rank), Hungary (45 th Rank), Kuwait (44th Rank), Montenegro (41 st Rank) needs to undertake more serious measures on equitable distribution of wealth for balanced growth. Some Lower Middle Income and Lower income countries are seen to perform better than other countries in Financial Inclusion. These countries are Morocco (40th Rank), Srilanka (55 th Rank), India (63 ${ }^{\text {rd }}$ Rank), Bangladesh (65 th Rank) and Guatemala (66 $6^{\text {th }}$ Rank). Correlation and regression were conducted to find relationship, if any between global GDP levels and global financial inclusion levels. It was found that GDP is a significant predictor of FI with correlation value at $.666^{* * *}$, and regression value at $.443 * * *$. It can be concluded that a unit change in global GDP will contribute to 40 percent change in FI levels across the world.

In spite of the high correlation found between GDP and FI, the findings from the table reveal that having high GNI does not necessarily mean that the wealth is distributed equally among the population. In this era of growing awareness and global intolerance towards inequitable distribution of wealth, the governments of economies should aim and construe measures to distribute the income among the entire population and prevent concentrating the income in just the top layer. This equitable distribution of wealth will lead to higher Global human development levels.

\section{VALIDATION OF RELATIONSHIP BETWEEN GDP AND HDI WITH FI AS MEDIATING VARIABLE}

To validate the relationship between GDP and HDI and analyse whether FI acts as mediator, the following conceptual and statistical framework was developed.

Recognition of active intervention between the stimulus and the response is one of the premises of identifying a variable as mediator and leading to the formulation of mediating hypothesis. A variable functions as a mediator (M) when it follows the following conditions - variations in levels of independent variable (X) significantly account for variations in presumed mediator or path a, variations in mediator significantly accounts for variations in dependent variable (Y) or path $b$, when path a and path $b$ is controlled, the relation between independent and dependent variable ins no longer significant, ideally at zero in path c (Baron \& Kenny, 1986).

In this study, the mediation effect has been studied for the following categories:

1. Higher income countries - 38 Countries;

2. Higher Middle income countries - 37 Countries;

3. Lower middle and Lower Income countries - 42 Countries; 


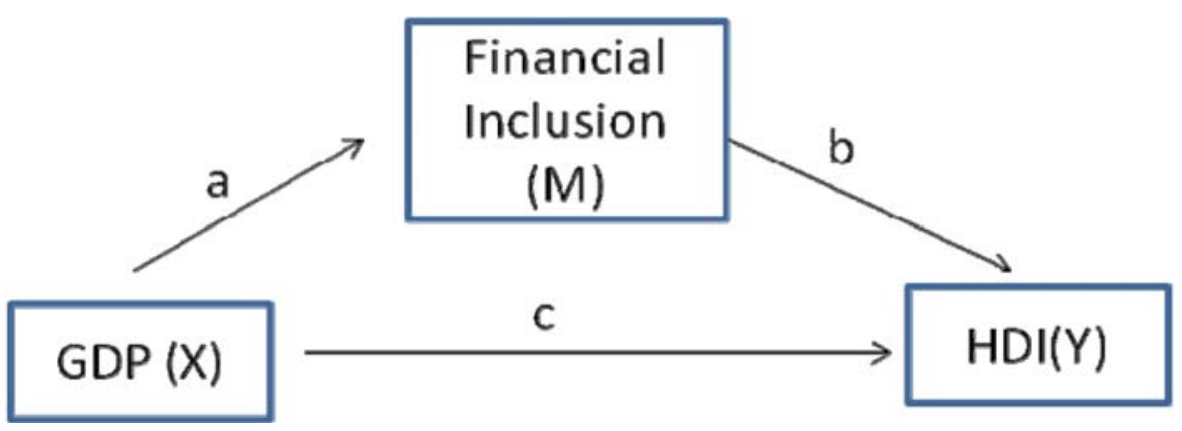

Figure 1. Conceptual Model showing relationship between GDP and HDI with Financial Inclusion as Mediator

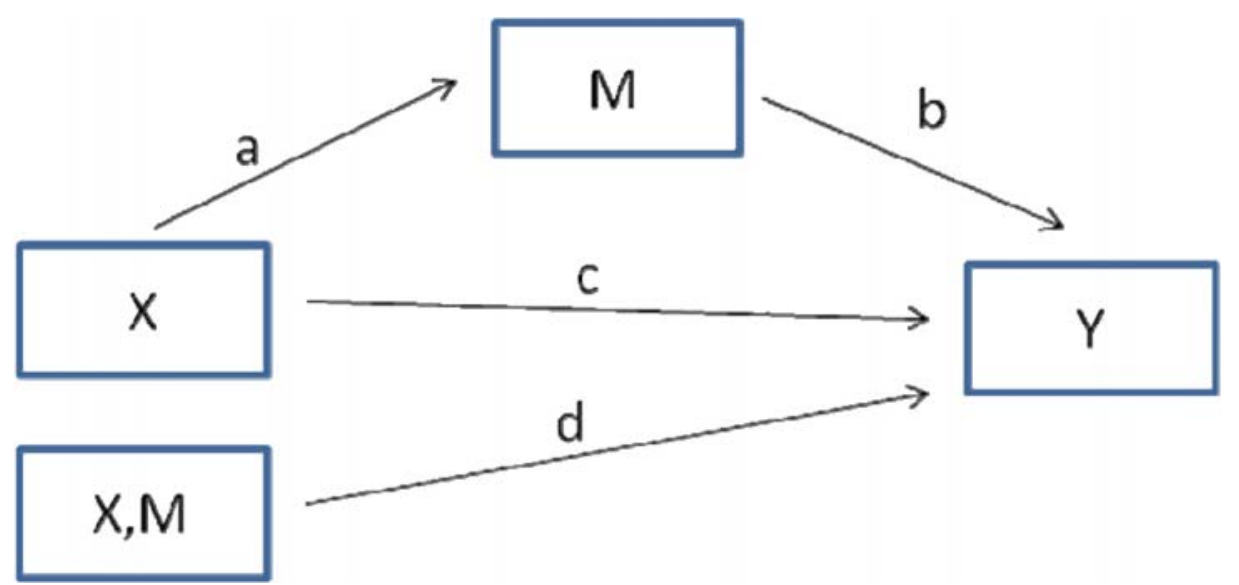

Figure 2. Statistical Model showing relationship between GDP and HDI with Financial Inclusion as Mediator

4. Global level $-1+2+3=117$ Development. The results of the analysis are Countries.

The mediation model is tested exclusively given as under.

With respect to High Income countries, for each of these categories using Simple the direct mediation effect is not significant Linear regression and Multiple Regression, to analyse the existence of mediation effect of Financial Inclusion on overall human as GDP is not seen as significant predictor of FI. The direct mediation effect of Financial Inclusion on human development for high

Table 3. Regression values of High Income Countries based on GDP, HDI and FI

\begin{tabular}{|c|c|c|}
\hline $\begin{array}{l}\text { Visual depiction } \\
\mathrm{X} \longrightarrow \mathrm{Y}^{1}\end{array}$ & Regression value $\left(r^{2}\right)$ & Significance level \\
\hline $\mathrm{GDP} \longrightarrow \mathrm{HDI}$ & .121 & $.032 *$ \\
\hline $\mathrm{GDP} \longrightarrow \mathrm{FI}$ & .087 & .072 \\
\hline $\mathrm{FI} \longrightarrow \mathrm{HDI}$ & .286 & $.001^{* *}$ \\
\hline $\mathrm{GDP}, \mathrm{FI} \longrightarrow \mathrm{HDI}$ & .326 & $.001 * *$ \\
\hline
\end{tabular}




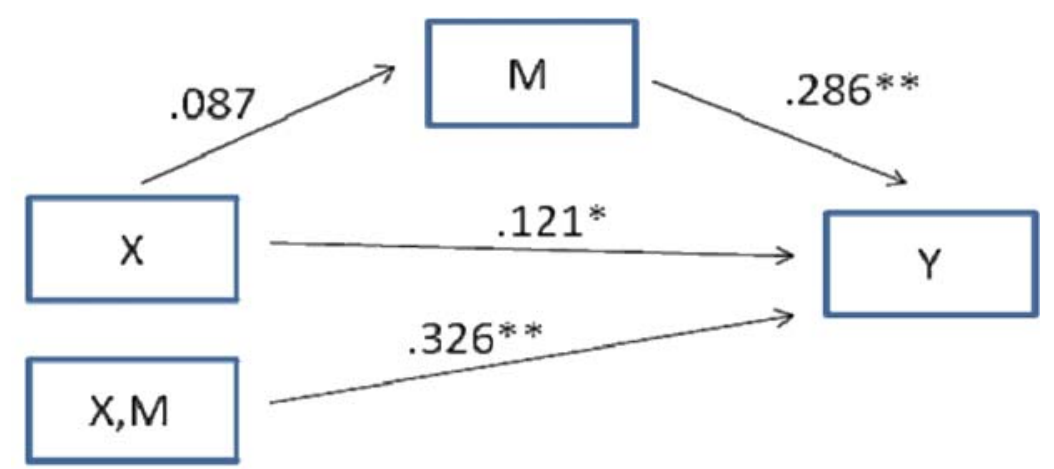

Source: Table 3

Figure 3. Regression values in Mediation model for High Income countries

income countries cannot be validated as per Baron and Kenny (1986) approach to mediation. However there exists an indirect effect i.e. $\mathrm{r}^{2}$ of GDP and HDI (.121*) is lesser than $\mathrm{r}^{2}$ of multiple regression of both GDP and FI on HDI $\left(.326^{* *}\right)$. This proves that there exists an indirect mediation effect of FI on human development. As per Judd and Kenny (1981) the difference between $r^{2}$ of
GDP and HDI (.121*) denoted as $B$ and $\mathrm{r}^{2}$ of multiple regression of both GDP and FI on HDI $\left(.326^{* *}\right)$ denoted as $B_{1}$ gives the indirect effect $B_{\text {indirect }}=B-B_{1}$ as .205 . This denotes that FI is an indirect predictor for HDI and changes in FI will result in up to 20 percent changes in human development with respect to High Income countries.

Table 4. Regression values of High Middle Income Countries based on GDP, HDI and FI

\begin{tabular}{lll}
\hline Visual depiction & Regression value $\left(\mathrm{r}^{2}\right)$ & Significance level \\
$\mathrm{GDP} \longrightarrow \mathrm{Y}^{1}$ & & $.003 * *$ \\
$\mathrm{GDP} \longrightarrow \mathrm{HDI}$ & .219 & .590 \\
$\mathrm{FI} \longrightarrow \mathrm{FI}$ & .008 & .110 \\
$\mathrm{GDP}, \mathrm{FI} \longrightarrow$ HDI & .071 & $.002 * *$
\end{tabular}

${ }^{1}$ Where $\mathrm{X}=$ Independent Variable and $\mathrm{Y}=$ Dependent variable; ${ }^{*} \mathrm{p}<0.05,{ }^{* *} \mathrm{p}<0.01,{ }^{* * *} \mathrm{p}<0.001$

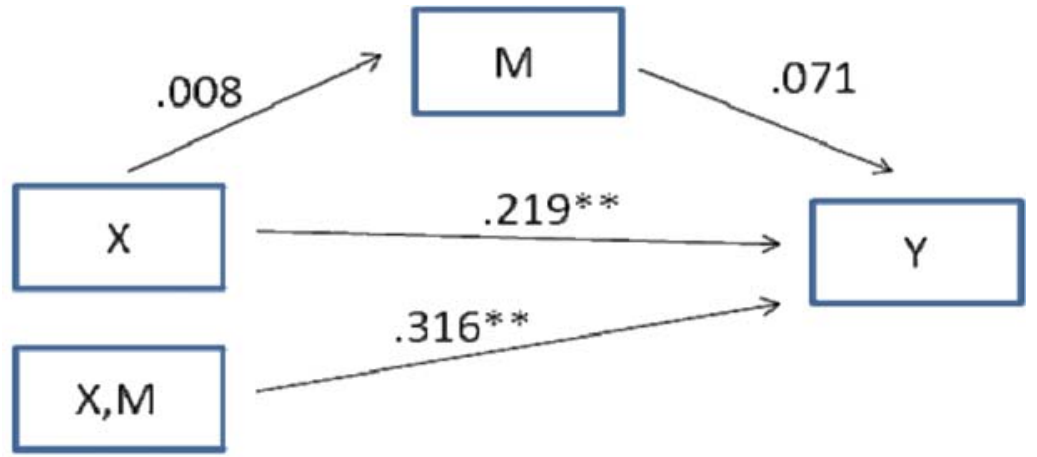

Source: Table 4

Figure 4. Regression values in Mediation model for High Middle Income countries 
With respect to higher medium Income countries, the direct mediation effect is not significant as GDP is not a significant predictor of FI and FI is not a significant predictor of HDI. The direct mediation effect is insignificant as per studies by Baron and Kenny (1986). As per Judd and Kenny (1981) the difference between $r^{2}$ of GDP and HDI $\left(.219^{* *}\right)$ denoted as $B$ and $\mathrm{r}^{2}$ of multiple regression of both GDP and FI on HDI $\left(.316^{* *}\right)$ denoted as $B_{1}$ gives the indirect effect $B_{\text {indirect }}=B-B_{1}$ as .097 . It can be concluded that the indirect effect is low at hardly 10 percent change in HDI happening to every unit change FI level. The mediation effect cannot be established for higher middle income countries significantly via both direct and indirect methodology.
The lower middle and lower income countries have high mediating influence on HDI with all the relationships between predictors and dependent variables significant to establish a mediating effect of FI on HDI. The direct effect as per studies by Baron and Kenny (1986) shows a significant relationship between FI and HDI and FI as a significant direct predictor of HDI. The indirect effect stands at $.09\left(B_{\text {indirect }}=B-B_{1}\right)$. The direct effect with partial mediation on human development is considerably more significant than the indirect effect.

The global levels of FI reveals that there exists a partial mediation between FI and HDI as the variables GDP and FI are seen as significant predictors of HDI in all the $r^{2}$ Values showing direct mediation effect as

Table 5. Regression values of Lower Middle Income and Lower Income Countries based on GDP, HDI and FI

\begin{tabular}{|c|c|c|}
\hline $\begin{array}{l}\text { Visual depiction } \\
\mathrm{X} \stackrel{\mathrm{Y}^{1}}{\longrightarrow}\end{array}$ & Regression value $\left(\mathrm{r}^{2}\right)$ & Significance level \\
\hline $\mathrm{GDP} \longrightarrow \mathrm{HDI}$ & .483 & $.000^{* * *}$ \\
\hline $\mathrm{GDP} \longrightarrow \mathrm{FI}$ & .092 & $.049 *$ \\
\hline $\mathrm{FI} \longrightarrow \mathrm{HDI}$ & .249 & $.001 * *$ \\
\hline $\mathrm{GDP}, \mathrm{FI} \longrightarrow \mathrm{HDI}$ & .573 & $.000^{* * *}$ \\
\hline
\end{tabular}

${ }^{1}$ Where $\mathrm{X}=$ Independent Variable and $\mathrm{Y}=$ Dependent variable; ${ }^{*} \mathrm{p}<0.05,{ }^{* *} \mathrm{p}<0.01,{ }^{* * *} \mathrm{p}<0.001$

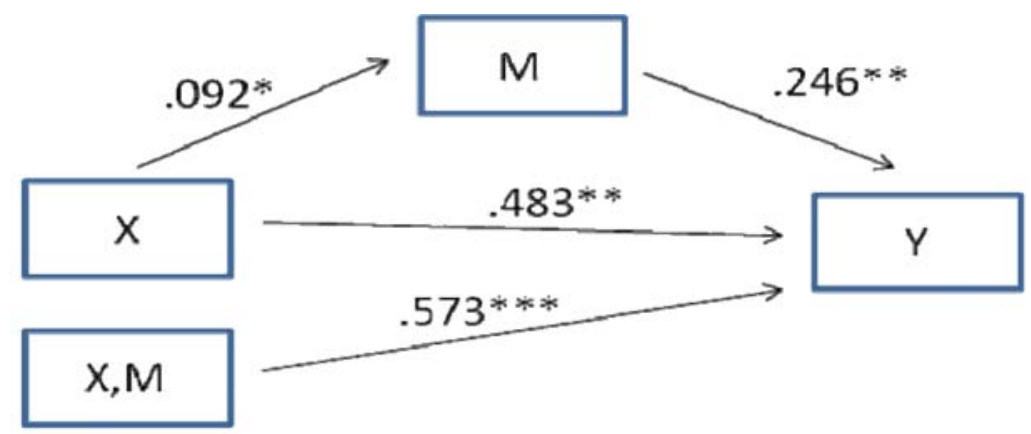

Source: Table 5

Figure 5. Regression values in Mediation model for Lower Middle Income and Lower Income Countries 
Table 6. Global Regression values based on GDP, HDI and FI

\begin{tabular}{|c|c|c|}
\hline $\mathrm{X} \stackrel{\text { Visual depiction }}{\longrightarrow} \mathrm{Y}^{1}$ & Regression value $\left(\mathrm{r}^{2}\right)$ & Significance level \\
\hline $\mathrm{GDP} \longrightarrow \mathrm{HDI}$ & .436 & $.000^{* * *}$ \\
\hline $\mathrm{GDP} \longrightarrow \mathrm{FI}$ & .443 & $.000^{* * *}$ \\
\hline $\mathrm{FI} \longrightarrow \mathrm{HDI}$ & .543 & $.000^{* * *}$ \\
\hline $\mathrm{GDP}, \mathrm{FI} \longrightarrow \mathrm{HDI}$ & .595 & $.000^{* * *}$ \\
\hline
\end{tabular}

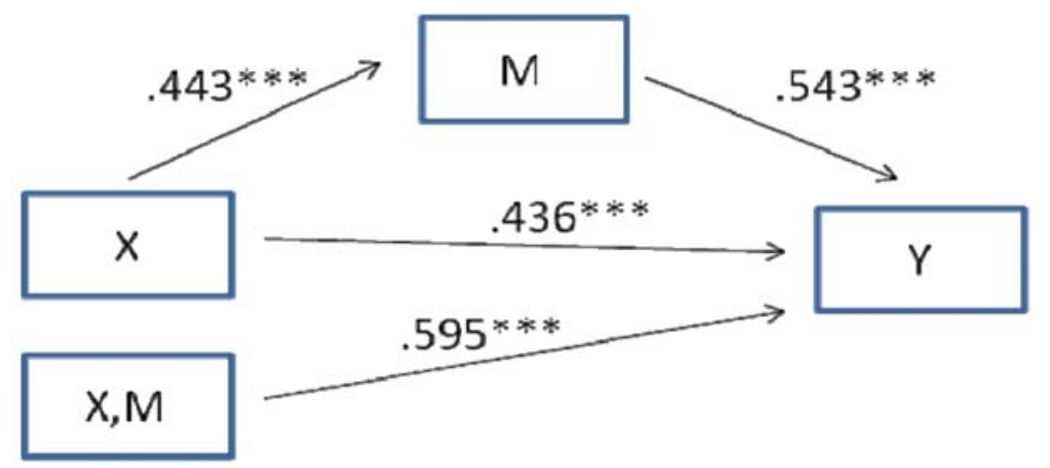

Source: Table 6

Figure 6. Global Regression values in Mediation model

per Baron and Kenny (1986). There exists a partial direct mediation as when FI is controlled too there exists highly significant relationship between GDP and HDI at $0.436^{* * *}$. The indirect mediation effect, as per Judd and Kenny (1981) - the difference between $\mathrm{r}^{2}$ of GDP and HDI $\left(0.436^{* * *}\right)$ denoted as $B$ and $\mathrm{r}^{2}$ of multiple regression of both GDP and FI on HDI $\left(0.595^{* * *}\right)$ denoted as $B_{1}$ gives the indirect effect $B_{\text {indirect }}=B-B_{1}$ as 0.159 . It can be concluded that on a global level FI has both direct and indirect effect on human development. This proves that previous study findings that equitable distribution is a major factor resulting in higher human development than mere GDP figures showing rise in Income levels in and economy.

\section{CONCLUSION}

GDP as a significant predictor of FI is significant only in the context of lower middle and lower income countries (.092*). It can be concluded that merely possessing high income in terms of GDP does not enable balanced growth in an economy. Changes in Financial inclusion levels is seen to affect overall human development directly in the high income $\left(.286^{* *}\right)$ and lower middle and lower income category $\left(.246^{* *}\right)$ of countries. It can be concluded that there is still no established relationship or correlation between human development and financial inclusion in higher middle income countries. The higher human development in Higher middle and higher income countries re a result of higher national average in life 
expectancy and education than higher income levels. These conclusions substantiate the previous findings that human development cannot be just a result of national average, but should incorporate three aspects, national average, equity and deprivation (Fukuda-Parr, 2011). Furthermore, the basic computation of HDI has been criticised that relative weights bias the results towards favouring a particular aspect of development (Cahill, 2005). It can be concluded that any change in Financial Inclusion levels indirectly boost the overall human development in an economy.

The relevance of the finding is valid to economies across the world, which are struggling to infuse fresh capital in a quest for growth and higher human development. The current study suggests that rather than trying to infuse more capital through external debt from global regulatory and banking institutions like IMF and World Bank, it will be beneficial and progressive in the long run towards balanced human development if the economies focus more on distributing the income and resources within the economy to include all of the population. The current trend of economies irrespective of their standing as on the basis of income is to look outwards for financial aid rather than leveraging existing resources for growth and stability of the economy. Financial Inclusion is a result of equitable wealth creation and distribution and can contribute substantially to overall human development in a global context.

To attain desired levels of financial inclusion, the need of the hour is the adoption of technology on the lines of Unique Identification authority of India, better known as Aadhaar. The challenge of Aadhar is to bring identity to each and every citizen of the second most populous country of the world with the aid of technology (Unique identification authority of India, 2012). The project which is still on a large scale enrolment drive, aims to ultimately bring financial inclusion to a larger section of the society currently excluded from the formal banking system, with no access to credit, heavily relying on unorganised sector for capital and credit requirements. The current measures of Keynesian theory which propagates fiscal reforms and measures with taxation as a cornerstone to achieve equitable distribution and maximise human development has not been able to achieve the desired result, as is evident from the data sources used in the study. The reasons for this failure has largely been that the benefits are not reaching the intended because of various reasons as varied as misappropriation of money from middlemen to the inability of the authorities to identify the financially deprived and the extent of depravity. Active government intervention with the aid of technology is sure to bring reforms to the current financial system with equitable financial development and result in the world being a "better place" to live in.

\section{References}

Arranz Garcia, J.D., \& Vicente Lorente, J.D. (2014). Exploring the link between managerial outcomes and investment performance of entrepreneurs. Serbian Journal of Management, 9(2), 183 - 202.

Baron, R.M., \& Kenny, D.A. (1986). The Moderator-Mediator variable distinction in Social Psychological Research: Conceptual, Strategic and Statistical Considerations. Journal of Personality and Social Psychology, 51 (6), 1173 -1182. 


\title{
ИСТРАЖИВАЊЕ ГЛОБАЛНИ НИВОА ФИНАНСИЈСКЕ ИНКЛУЗИЈЕ И АНАЛИЗА ФИНАНСИЈСКЕ ИНКЛУЗИЈЕ КАО ПОСРЕДНОГ ФАКТОРА ГЛОБАЛНОГ ЉУДСКОГ РАЗВОЈА
}

\author{
Roshny Unnikrishnan, Lakshmi Jagannathan
}

\section{Извод}

Ова студеија је резултат истраживања аутора у изналажењу тренутних вредности глобалне финансијске инклузије и њених односа са економским растом, измереним преко бруто домаћег продукта (БДП) и развојем човечанства, мереним индексом развоја човечанства Уједињених нација (ХДИ). Нивои финансијске инклузије (ФИ) су измерени употребом индекса финансијске инклузије. Однос БДП и ХДИ, уз ФИ као медијатора проучен је преко вишеструке регресије и валидација је урађена на глобалном нивоу уз употребу података из 162 земље за 2011. годину. Укупна глобална медијациона анализа је учињена како би се успоставила финансијска инклузија као посредни фактор и парцијални утицај на развој човечанства је потврђен. Ова студија је валидна и јединствена у глобалном контексту у контексту неједнакости прихода који постоји између развијених, земаља у развоју и неразвијених земаља. То потврђује аргумент да импресивне БДП перформансе не условљавају увек једнакост у економском расту.

Кључне речи: бруто домажи производ (БДП), финансијска инклузија (ФИ), индекс развоја човечанства (ХДИ), анализа посредног утицаја, вишеструка регресиона анализа

Cahill, M.B. (2002). Diminishing returns to GDP and the Human Development Index. Applied Economics Letters, 9 (13), 885-887.

Cahill, M.B. (2005). Is the Human Development Index redundant?. Eastern Economic Journal, 31 (1), 1-5.

Demigrguc-Kunt, A., \& Klapper, L. (2012). Measuring Financial Inclusion: The Global Findex Database. Policy Research Working Paper 6025. The World Bank, Development Research Group, Finance and Private sector development team. Retrieved from http://wwwwds.worldbank.org/servlet/WDSContentSer ver/WDSP/IB/2012/04/19/000158349_2012 0419083611/Rendered/PDF/WPS6025.pdf.

Federal Reserve Bank of St. Louis. (2013). Bank Deposits to GDP for Canada, 2008.
http://research.stlouisfed.org/fred2/series/D DOI02CAA156NWDB

Fukuda-Parr, S. (2001). Indicators of human development and human rights -overlaps, differences ... and what about the human development index? Statistical Journal of the UN Economic Commission for Europe, 18 (2/3), 239-249.

Hajro, Z., \& Joyce J.P. (2009). A true test: do IMF programs hurt the poor? Applied Economics, 41 (3), 295-306.

Henderson, H. (1996). What's Next in the Great Debate About Measuring Wealth and Progress? Challenge, 39 (6), 50-56.

International Monetary Fund. (2013). World economic and financial surveys World Economic outlook, April 2013. http://www.imf.org/external/pubs/ft/weo/20 13/01/pdf/text.pdf. Accessed 24 July 2013. 
International Monetary Fund. (2012). World Economic Outlook Update -New Setbacks, Further Policy Action Needed. Retrieved from http://www.imf.org/external/pubs/ft/weo/20 12/update/02/index.htm.

Judd, C.M., \& Kenny, D.A. (1981). Process Analysis: Estimating Mediation in Treatment Evaluations. Evaluation Review, 5 (5), 602-619. Retrieved from http://ripl.faculty.asu.edu/wp content/uploads/2013/02/Judd-Kenny1981b.pdf.

King, R.G., \& Levine, R. (1993). Finance and Growth: Schumpeter might be right. The Quarterly Journal of Economics, 108, 717736.

Kumar, B., \& Mohanty, B. (2011). Financial Inclusion and Inclusive Development in SAARC Countries with Special Reference to India. Vilakshan: The XIMB Journal of Management, 8 (2), 13-22.

Landefeld, J.S., Seskin, E.P., \& Fraumeni, B.M. (2008). Taking the Pulse of the Economy: Measuring GDP. Journal of Economic Perspectives, 22 (2), 193-216.

Levine, R., \& Zervos, S. (1998). Stock Markets, Banks and Economic Growth. The American Economic Review, 88 (3), 537558.

Low, L., \& Aw, T.C. (1997). The Human Development Index Revisited. Singapore Management Review, 19 (1), 1-17.

Luchters, G., \& Menkoff, L. (2000). Chaotic signals from HDI measurement. Applied Economics Letters, 7 (4), 267-270.

Nagadevara, V. (2009). Identifying Supply and Demand side factors that Influence Financial Inclusion: An application of ANNs. Journal of International Business and Economics, 9 (4), 88-93.

Nissan, E., \& Shahmoon, R. (1993). An Assessment of Human Development, by
Region and Country. Journal of Economics \& Finance, 17 (1), 31-43.

Ogwang, T. (2000). Inter-country inequality in human development indicators. Applied Economics Letters, 7 (7), 443-446.

Osberg, L., \& Sharpe, A. (2005). How should we measure the "Economic" aspects of well-being?. Review of Income \& Wealth, 51 (2), 311-336.

Porter, J.R., \& Purser, C.W. (2008). Measuring Relative Sub-National Human Development: An Application of the United Nation's Human Development Index in the U.S. Journal of Economic and Social Measurement, 33 (4), 253-269.

Quotes on poverty: The Samuel Johnson Sound Bite Page. http://www.samueljohnson.com/poverty.htm 1\#90. Accessed 20 July 2013.

Sarma , M. (2008). Working paper no: 215, Index of Financial Inclusion. Indian Council for Research on International Economic Relations. Retrieved from http://www.icrier.org/pdf/Working_Paper_2 15.pdf.

The World Bank. (2013). Commercial bank branches (per 100,000 adults). Retrieved from http://data.worldbank.org/indicator/FB.CBK .BRCH.P5.

The World Bank. (2013). Domestic credit provided by banking sector ( $\%$ of GDP). Retrieved from http://data.worldbank.org/indicator/FS.AST. DOMS.GD.ZS.

The World Bank. (2013). Financial Inclusion data. Retrieved from http://datatopics.worldbank.org/financialincl usion/

Tokuyama, C., \& Pillarisetti, J.R. (2009). Measuring and monitoring human welfare: How credible are the data in the UNDP's human development reports? Journal of 
Economic \& Social Measurement, 34 (1), $35-50$.

Unique identification authority of India. (2012, Jan). ( Planning commision - Govt of India) Retrieved Dec 26, 2012, from http://uidai.gov.in/about-uidai.html

United Nations. (2012). Statistical Annex: Country classification . Retrieved from http://www.un.org/en/development/desa/poli cy/wesp/wesp_current/2012country_class.p df.

United Nations Data - A World of Information. (2012). Per capita GDP at current prices - US dollars. Retrieved from http://data.un.org/Data.aspx?q=GDP\&d=SN AAMA\&f $=$ grID $\% 3 a 101 \% 3$ bcurrID $\% 3 a U S$ D\%3bpcFlag\%3a1.

United Nations Development program. (2012). Human Development Index trends, 1980-2012. Retrieved from http://data.un.org/DocumentData.aspx? $\mathrm{q}=\mathrm{H}$ uman + development + Index $+\& \mathrm{id}=327$.

US Department of Commerce, Bureau of Economic Analysis. (2000). GDP: One of the Great Inventions of the 20th Century. Retrieved from http://www.bea.gov/scb/account_articles/ge neral/0100od/maintext.htm. 